Journal of Nepal Agricultural Research Council

Vol. 7: 151-160, April 2021

ISSN: 2392-4535 (Print), 2392-4543 (Online)

DOI: https://doi.org/10.3126/jnarc.v7i1.36941

\title{
Evaluation of Broad Leaf Mustard Genotypes in Central Mid-hill of Nepal
}

\author{
Surendra Lal Shrestha ${ }^{\circledR}$, Suprabha Pandey, Yadav Kumar Shrestha and Iswori Prasad Gautam \\ National Horticulture Research Center, NARC, Khumaltar, Lalitpur, Nepal; @: shsurendra@ @otmail.com; \\ (DD : https://orcid.org/0000-0003-1109-6514; SP:<suprabhapandey52@gmail.com>; IPG: \\ ishworigautam@gmail.com
}

Received 26 Sept 2020, Revised 07 Jan 2020, Accepted 27 March 2021, Published 30 April 2021

Scientific Editors: Umesh Kumar Acharya, BK Joshi, and Jiban Shrestha

Copyright $(\mathrm{C} 2021$ NARC. Permits unrestricted use, distribution and reproduction in any medium provided the original work is properly cited.

The authors declare that there is no conflict of interest.

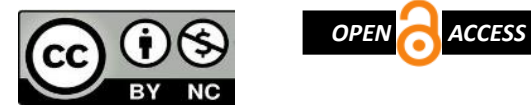

Licensed under the Creative Commons AttributionNonCommercial 4.0 International (CC BY-NC 4.0)

\section{ABSTRACT}

Seven genotypes of broad leaf mustard were evaluated for their performance at research field of Khumaltar, Lalitpur, Nepal in winter season of consecutive three years; 2016, 2017 and 2018. The main objective of these studies was to find out the most promising genotypes of broad leaf mustard. The experiments were conducted in randomized complete block design with three replications. Three weeks old seedlings were transplanted on first week of October at the spacing of $45 \mathrm{~cm} \times 30 \mathrm{~cm}$. Fertilizer was applied at the rate of 200:150:100 NPK kg/ha and 15ton compost per hectare and other cultural practices was carried out as per recommendation of National Horticulture Research Centre, Khumaltar, Lalitpur, Nepal. Fresh consumable fully developed green leaves were harvested frequently; seven to ten days interval. In the present study, wide genetic variability was observed on plant vigor, insect, disease, leaf length $(\mathrm{cm})$, leaf width $(\mathrm{cm})$, leaf harvest yield in number and weight, and consumer's response recorded. On the basis of overall characteristics, among the evaluated genotypes; HRDBLM010 showed superior performance with good uniformity, vigorous growth, moderately resistant with insects pest and disease (2.1), bigger leaf size $(44.2 \times 27.5 \mathrm{~cm})$, least petiole length $(0.93 \mathrm{~cm})$, significantly higher leaf yield in number (25) and weight (748 g/plant and $51.24 \mathrm{t} / \mathrm{ha})$, medium late bolting, good taste has been selected for cultivation at central mid-hills (Kathmandu valley) condition of Nepal. The next promising genotype is HRDBLM004 which had also good uniformity, vigorous, less damage by insect (2.4) and disease (2.5), higher yield in number (41) and weight (848 g/plant and $60.10 \mathrm{t} / \mathrm{ha}$ ) and softness. These two genotypes have been found promising genotypes for cultivation in central mid-hills of Nepal.

Keywords: Broad leaf mustard, consecutive years, leaf, leaf size, mid-hills, yield

\section{सारांश}

नेपालको विभिन्न क्षेत्रबाट संकलित र विगतको बर्षमा अनुवांशिक शुद्धता सुधारिएको रायोका सात वटाजिनोटाइपहरुको सन् २०१६ देखि लगातार तीनबर्षसम्म खुमलटार (१२बलमऐ मी) मा मुल्यांकन गरिएको थियो । यो परिक्षणको मुख्य उद्देश्य सबैभन्दा राम्रो रायोको जात छनौट गर्नु थियो। तीन हप्ता पुगेका बिरुवाहरु अक्टोबरको पहिलो सातामा $४ Y$ से.मी $X$ ३० से.मी को दूरीमा तीन रेप्लिकेशनमा रोपिएको धियो । १५ टन प्रति हेक्टर गोबरमल र २००: १५०: १०० ना.फो.पो.को दरले रासायनिक मल प्रयोग गरिएको थियो। यसमा नाइट्रोजनको आधा मात्रा बेर्ना सार्ने बेलामा र बाकी आधामात्रा दुइपटक गरी दिएको थियो । ताजा उपभोग्यपूर्ण विकसित हरियो पातहरु केही दिनका फरकमा लगातार टिपियो। हाल गरिएको अध्ययनमा बोटको बृद्धी, रोग, कीरा, पातको लम्बाई (से.मी.), पातको चौडाई (से.मी), उपभोग्य पातको उत्पादन (संख्या र तौल) र उपभोक्ताको प्रतिक्रिया अध्यधनमा बिस्तृत अनुवांशिक भिन्नता देखियो। परिक्षण गरिएका जिनोटाइप बीच समग्र गुणहरुको आधारमा HRDBLM010 ले राम्रो प्रदर्शन देखाएको पाइयो जसमा बोटको एकरुपता, बोटको उत्तम बृद्धी, रोग र कीरासंग लड़े मध्यम प्रतिरोधी क्षमता, ठूलो पातको आकार, छोटो पिटिवल लम्बाई र उल्लेखनीय रुपमा अधिक पात उत्पादन संख्या (२५) र तौल (बलम४५ ग्राम प्रतिबोट र भ१. २४ टन प्रति हेक्टर, मध्यम ढिलो फूल्े र राम्रो स्वाद पाइयो जसको खेती गर्न योग्य ठाउँ नेपालको मध्यपहाडी (काठमाडौं उपत्यका) क्षेत्र छनौट गरिएको छ। अर्को आशाजनक र राम्रो जिनोटाईप HRDBLM004 हो जसले राम्रो एकरुपता , परिपक्वता , किरा र रोगले कमक्षति गर्ने, संख्यामा र तौलमा बढी उत्पादन र पातमा नरमता पाइयो। यी दुई जिनोटाइपहरु नेपालको मध्यपहाडी क्षेत्रमा खेतीका लागि सिफारिस गरिएको छ। 


\section{INTRODUCTION}

Broad Leaf Mustard (BLM), Brassica juncea var. rugosa., native to sub-Himalayan plains of the Indian sub-continent belonging to family Cruciferae, is one the most popular, highly commercial, and most widely grown leafy vegetables in Nepal. Broad leaf mustard (Brassica juncea L) is a cruciferous, quick maturing, easy to grow, cool season vegetables that are commonly used cooked and as salad greens which has numerous common names, such as brown mustard, Chinese mustard, and oriental mustard (Kumar et al 2011) and Rayo ko sag in Nepali (Parajuli 2015). The BLM plant is famous for its leaves and oil seeds since ancient times. Mustards are cool season winter crop. Their tender, crispy leaves are more flavorful which last from November until March.

It is grown as winter crop (terai to mid hills) and summer crop (high to mid hills). In cold condition quality of leaves is found better than warm condition (Parajuli 2015). A 100 grams of cooked mustard greens provide 26 calories energy. It is also a rich source ( $20 \%$ or more of the Daily Value) of vitamins $\mathrm{A}, \mathrm{C}$, and $\mathrm{K}$ which is especially high as a multiple of its daily value.Similarly, minerals like $\mathrm{Cu}, \mathrm{Mn}$ and $\mathrm{Ca}$ can be obtained from its consumption (www.wikipedia.org). Broad leaf mustard are a moderate source of vitamin $\mathrm{E}$ and calcium containing $92 \%$ water, $4.5 \%$ carbohydrates, $2.6 \%$ protein and $0.5 \%$ fat (www.badplants.com). The leaves are ovate or obovate, simple and petioled; the flowers of the raceme inflorescences are bisexual, with four free sepals and four yellow petals, along with two longer and two shorter stamens (Szollosi 2011). Fresh BLM leaves feature deep green, broad leaves with a flat surface and may have either toothed, frilly or lacy edges depending on the cultivar type. Its light-green stem branches out extensively into many laterals (NPMS 2015).

In Nepal, it is cultivated in an area of 12,996 ha of land with the national production of $1,86,897$ ton, and productivity of BLM has recorded $14.83 \mathrm{t}$ ha-1(MOALD 2020). In balanced diet for one matured person needs $300 \mathrm{~g}$ of vegetables where green leafy vegetable needs to have $50 \mathrm{~g}$ per day (Petre 2017). BLM is a major green leafy vegetable in Nepal. In Nepal, BLM is mainly produced for local consumption targeting to the local markets and produced in different areas (Regmi et al 2005). Specially, it is popular in urban and peri urban areas of Nepal. Broad Leaf Mustard is also consumed in the form offermented product, locally known as Gundruk which is most popular and favorite Nepali side dish. During winter season, it is mandatory as rayoko sag in most of the Nepali kitchen. As it is cross pollinated crop, true varietal maintenance is a major problem. Hence, location specific cultivars are grown in different places of Nepal with some segregation of the population. Till now, very few varieties; Khumal chaudapat, Khumal ratopat, Tankhuwa rayo, Marpha chaudapat, Maic Zaint have been released in Nepal (SQCC 2019). In addition, some native landraces of BLM have been registered (Joshi et al 2017). Farmers and consumers need to have choices for location specific and consumer's desired specific varieties. Beside this, without proper registration and released varieties, seed production could take follow the system of the country.

The existence of genetic variability among population is the most important rationale for judicious selection and breeding of desired plant genotypes (Singh et al 2005). Productivity of the mustard is influenced by genotypes as well as time of sowing (Meena et al 2017). Knowing the degree of genetic variability and its magnitude is a prerequisite to develop a sound crop improvement program in any plant (Welsh 1990). High yielding, insect disease tolerant, late bolting and tasty cultivars are the demand of these days. Thus, the main objective of the experiment was to find out the most promising variety of broad leaf mustard.

\section{MATERIALS AND METHODS}

\section{Experimental location}

The research field of National National Horticulture Research Centre is located at an altitude of 1275 $\mathrm{m}$, latitude of $27^{\circ} 40^{\prime} \mathrm{N}$ and longitude of $085^{\circ} 20^{\prime} \mathrm{E}$ (NHRC, 2019). Soil type of the experimental plot was black and sandy loam in texture, slightly acidic and medium in organic matter (NHRC 2019). 


\section{Plant materials}

Five genotypes of broad leaf mustard were collected from different parts of the country; HRDBLM001 (Central terai), HRDBLM004(Eastern hill), HRDBLM007(Western hill), HRDBLM009(Mid-west hill), HRDBLM010(Central hill) and one from Thailand (HRDBLM003). These genotypes were being grown for three years for the characterization and maintenance of desired traits in the screen house of National Horticulture Research Centre (NHRC) Khumaltar before conducting this experiment. The widely adopted most popular released variety Marpha chaudapat has been used as local check. The detail information of these genotypes is mentioned in Table 1. Due to early bolting, more susceptibility to the disease and lesser yield, genotype HRDBLM003 was excluded from the study in the third year.

Table 1. Source and specific feature of the broad leaf mustard genotypes

\begin{tabular}{|c|c|c|c|}
\hline Assigned Name & Collected Site & Collected Year & Specific feature \\
\hline HRDBLM001 & Janakpur & 2070 & Green and smooth leaf, late bolting \\
\hline HRDBLM003 & Thailand & 2070 & Green and rough leaf, early bolting \\
\hline HRDBLM004 & Okhaldhunga & 2070 & Dark green, thick and smooth leaf, medium bolting \\
\hline HRDBLM007 & Kaski & 2068 & $\begin{array}{l}\text { Dark green leaf with red vein, good for rainy } \\
\text { season, medium bolting }\end{array}$ \\
\hline HRDBLM009 & Dailekh & 2072 & Smooth and light green leaf, late bolting \\
\hline HRDBLM010 & Bhaktapur & 2071 & Dark green, loby leaf, late bolting \\
\hline Marpha Chaudapat & & 2070 & Smooth green leaf, late bolting \\
\hline
\end{tabular}

\section{Climatic data}

The meteorological data for cropping season was recorded from the meteorological station of Khumaltar, Lalitpur, Nepal. The average maximum and minimum mean daily temperature were $21.3^{\circ} \mathrm{C}$ and $4.8^{\circ} \mathrm{C}$, respectively in $2016,21.8^{\circ} \mathrm{C}$ and $8.5^{\circ} \mathrm{C}$, respectively in 2017 and $20.3^{\circ} \mathrm{C}$ and $7.5^{\circ} \mathrm{C}$, respectively in 2018 . Similarly average relative humidity was $50.3 \%, 51.7 \%$ and $50.7 \%$ in 2016, 2017 and 2018 respectively, and mean rainfall was $272 \mathrm{~mm}, 157 \mathrm{~mm}$ and $332 \mathrm{~mm}$ during the growing period in 2016, 2017 and 2018 respectively (www.http//worldweatheronline/lalitpurweatheraverages/np.aspx).

\section{Experimental design, treatment details}

The experiments were conducted in randomized complete block design with three replications. Three weeks old seedlings of seven genotypes; HRDBLM001, HRDBLM003, HRDBLM004, HRDBLM007, HRDBLM009, HRDBLM010 and Marpha chaudapat were transplanted in first week of October at the spacing of $45 \mathrm{~cm} \times 30 \mathrm{~cm}$ in four replications in three consecutive years; 2016, 2017 and 2018. Plot size was maintained with 20 plants per plot.

\section{Cultural practices}

Fertilizer was applied at the rate of 200:150:100 NPK kg and 15 ton compost per hectare with three split dose of nitrogen. NPK fertilizer was applied through Urea, DAP and MOP. Urea was applied three times; first half during planting, then other half was applied in two split doses; after first picking and third picking of leaves. Minimum insecticide and fungicide were sprayed. This experiment was conducted in National Horticulture Research Centre, Khumaltar, Lalitpur in open field condition.

\section{Data observation and data analysis}

Tender fully developed leaves were harvested frequently and number and weight recorded in each harvest. Plant uniformity and vigor was recorded just before first harvest ( 25 days after transplanting) in 1 to 5 scale (1: unacceptable to 5: excellent). Leaf size (length, width, petiole length) was measured in second, third and fourth harvested time with 5 leaves each time and calculated average). Likewise, insect (aphid, leaf eating caterpillar) and disease (alternaria leaf spot, white rust) were recorded in different stages in 1 to 5 scale (1: no symptom, 5: heavy damage) as described by Dinssa et al (2015) and Gotame et al (2019) as follows.

Plant status Score (1-5)

Healthy plants $=1$

About 25\% leaves of the plants infested $=2$ 
About $50 \%$ leaves of the plants infested $=3$

About $75 \%$ leaves of the plants infested $=4$

About $100 \%$ leaves of the plants infested $=5$

As all the harvestable leaves were removed frequently, least damage by insect and disease occurred in newly developed leaves. Average leaf weight was calculated by dividing total number of leaves with total weight. Total number and total weight of leaves per plot was calculated by adding all the harvested leaves in different times. Number of leaves harvested per plant was calculated by dividing total number of harvested leaves with number of plants harvested. Likewise, yield (g) per plant was calculated by dividing total harvested weight with total number of plants. Yield ton per hectare was calculated by dividing total weight per plot with plot size and converted into ton $(1000 \mathrm{~kg})$ and hectare $\left(10000 \mathrm{~m}^{2}\right)$. Leaf characters; leaf blade shape, leaf surface, leaf division margin, leaf blade thickness, leaf color, taste was recorded during second harvest. Days to bolting was recorded when 50 percent plants gave flowers. No leaves were harvested after bolting. Observed data were analyzed using MS-Excel (Microsoft Excel.2010) and MSTAT-C package (Version 1.3). Means were separated with Duncan's Multiple Range Test (DMRT) at 5\% level of significance (Gomez and Gomez 1984).

\section{RESULTS}

\section{Plant uniformity and Plant vigor}

Plant uniformity was found significant different among the cultivars in all the tested years; 2016, 2017 and 2018 (Table 2). But the combined mean of plant uniformity was not significantly different, however, found more uniform in HRDBLM004 and HRDBLM003 (3.9) and lower was found in HRDBLM007 (3.3).

Likewise, plant vigor was found significant among the cultivars in year 2017 and 2018. The combined mean of plant vigor was found significantly higher in HRDBLM003 (4.1) as compared to cv. Marpha chaudapat and at par with HRDBLM010 and HRDBLM004.

Table 2. Plant Uniformity and Plant Vigor of broad leaf mustard genotypes during 2016, 2017 and 2018 , NHRC, Khumlatar

\begin{tabular}{llllllllll}
\hline Genotype & \multicolumn{4}{c}{ Plant uniformity (1-5) } & \multicolumn{3}{c}{ Plant vigor (1-5) } & \multicolumn{2}{c}{ Plant ht. cm } \\
\cline { 2 - 12 } & $\mathbf{2 0 1 6}$ & $\mathbf{2 0 1 7}$ & $\mathbf{2 0 1 8}$ & Average & $\mathbf{2 0 1 6}$ & $\mathbf{2 0 1 7}$ & $\mathbf{2 0 1 8}$ & Average & $\mathbf{2 0 1 6}$ \\
\hline HRDBLM001 & 4.2 & 3.0 & 3.3 & 3.5 & 4.2 & 3.0 & 3.0 & $3.4 \mathrm{bc}$ & 28.4 \\
\hline HRDBLM003 & 4.3 & 3.5 & - & 3.9 & 4.2 & 4.0 & - & $4.1 \mathrm{a}$ & 33.4 \\
\hline HRDBLM004 & 4.8 & 3.0 & 4.0 & 3.9 & 4.7 & 3.5 & 3.7 & $4.0 \mathrm{ab}$ & 28.1 \\
\hline HRDBLM007 & 4.2 & 3.0 & 2.7 & 3.3 & 4.3 & 3.0 & 2.0 & $3.1 \mathrm{c}$ & 27.1 \\
\hline HRDBLM009 & 4.0 & 3.0 & 3.3 & 3.4 & 3.8 & 3.0 & 2.3 & $3.0 \mathrm{c}$ & 27.8 \\
\hline HRDBLM010 & 4.8 & 3.0 & 3.7 & 3.8 & 4.7 & 3.5 & 3.7 & $4.0 \mathrm{ab}$ & 38.1 \\
\hline Marphachaudapat & 4.2 & 3.0 & 3.0 & 3.4 & 4.3 & 3.0 & 2.7 & $3.3 \mathrm{bc}$ & 26.7 \\
\hline Mean & 4.4 & 3.1 & 3.3 & 3.61 & 4.3 & 3.3 & 2.5 & 3.56 & 29.94 \\
\hline F-test & $*$ & $*$ & $*$ & $\mathrm{~ns}$ & $\mathrm{~ns}$ & $*$ & $*$ & $*$ & $*$ \\
\hline LSD (0.05) & 0.56 & .499 & 0.838 & & & 0.499 & 1.051 & 0.668 & 6.95 \\
\hline CV $(\%)$ & 7.30 & 10.3 & 13.75 & 7.64 & 12.91 & 8.6 & 19.7 & 10.54 & 14.4 \\
\hline
\end{tabular}

x1: unacceptable, 5: excellent. ns: Non-significant, $*$ Significant at 0.05 level of probability

\section{Insect and Disease}

Presence of insect among the genotypes was found to be non-significant in year 2016 and significant in 2017 and 2018. In both the years, HRDBLM010 had least insect damage. The combined mean of insect infestation was highest in HRDBLM001(2.7) followed by HRDBLM003 and Marpha (2.6) whereas lowest damage was found in HRDBLM010 (2.1) even though insect damage was not significant (Table 3). Insect damage was by larvae of diamond back moth and cabbage butterfly. Similarly, disease infestation was found to be non-significant in 2016 and significant in year 2017 and 2018. The combined mean of disease infestation was found to be highest in HRDBLM003 (3.0) followed by HRDBLM004 (2.5) and found lowest in HRDBLM007, HRDBLM009, HRDBLM010 (2.1) even though not significant among the varieties (Table 3). Disease includes leaf spot, white rust 
and some viruses. When specific rating of alternaria leaf spot is done, varietal effect on appearance of leaf spot was distinct in 2017 and 2018 where least infection was recorded in HRDBLM010 and HRDBLM007 in 2017 and 2018 and that is at par with Marpha (Table 4).

Table 3. Average Insect and Disease complex of broad leaf mustardgenotypes during 2016, 2017 and 2018 , NHRC, Khumaltar

\begin{tabular}{lllllllll}
\hline Genotypes & \multicolumn{4}{c}{ Insect complex (1-5) } & \multicolumn{3}{c}{ Disease complex (1-5) } \\
\cline { 2 - 9 } & $\mathbf{2 0 1 6}$ & $\mathbf{2 0 1 7}$ & $\mathbf{2 0 1 8}$ & Average & $\mathbf{2 0 1 6}$ & $\mathbf{2 0 1 7}$ & $\mathbf{2 0 1 8}$ & Average \\
\hline HRDBLM001 & 3.8 & 2.0 & 2.3 & 2.7 & 2.8 & 1.6 & 2.3 & 2.2 \\
\hline HRDBLM003 & 3.7 & 1.5 & - & 2.6 & 2.7 & 3.2 & - & 3.0 \\
\hline HRDBLM004 & 3.5 & 1.5 & 2.3 & 2.4 & 2.8 & 2.7 & 2.0 & 2.5 \\
\hline HRDBLM007 & 3.2 & 1.5 & 2.3 & 2.3 & 2.8 & 1.0 & 2.6 & 2.1 \\
\hline HRDBLM009 & 3.8 & 1.5 & 2.3 & 2.5 & 2.2 & 2.4 & 1.7 & 2.1 \\
\hline HRDBLM010 & 3.4 & 1.0 & 2.0 & 2.1 & 2.9 & 1.0 & 2.3 & 2.1 \\
\hline Marpha chaudapat & 3.5 & 2.0 & 2.3 & 2.6 & 2.9 & 1.6 & 2.0 & 2.2 \\
\hline Mean & 3.6 & 1.6 & 2.2 & 2.48 & 2.7 & 1.9 & 2.15 & 2.31 \\
\hline F-test & $\mathrm{ns}$ & $*$ & $*$ & Ns & ns & $* *$ & $*$ & $\mathrm{~ns}$ \\
\hline LSD (0.05) & & 1.306 & 0.5 & & & 1.011 & 0.48 & 24.87 \\
\hline CV (\%) & 9.95 & 22.8 & 13.45 & 8.41 & 9.5 & 30.2 & 24.88 \\
\hline
\end{tabular}

${ }^{\mathrm{x}}$ Leaf eating caterpillar, Diamond back moth, Cabbage butter fly. ${ }^{\mathrm{y}}$ Alternaria leaf spot, White rust, Powdery mildew and Virus

Table 4. Alternaria leaf spot and white rust of broad leaf mustard genotypes during 2016, 2017 and 2018 , NHRC, Khumaltar

\begin{tabular}{llllllll}
\hline \multirow{2}{*}{ Genotype } & \multicolumn{9}{c}{ Alternaria leaf spot (1-9) } & \multicolumn{2}{c}{ White rust (1-9) } \\
\cline { 2 - 8 } & $\mathbf{2 0 1 6}$ & $\mathbf{2 0 1 7}$ & $\mathbf{2 0 1 8}$ & Average & $\mathbf{2 0 1 6}$ & $\mathbf{2 0 1 7}$ & Average \\
\hline HRDBLM001 & 2.8 & 3.3 & 2.3 & $2.8 \mathrm{~b}$ & 2.5 & 2 & 2.2 \\
\hline HRDBLM003 & 2.7 & 6.3 & - & $4.7 \mathrm{a}$ & 3.5 & 2 & 2.7 \\
\hline HRDBLM004 & 2.8 & 5.3 & 2.0 & $3.7 \mathrm{ab}$ & 3.1 & 2 & 2.6 \\
\hline HRDBLM007 & 2.8 & 2.0 & 2.6 & $2.5 \mathrm{~b}$ & 3.3 & 2 & 2.7 \\
\hline HRDBLM009 & 3.2 & 4.7 & 1.7 & $3.2 \mathrm{ab}$ & 3.5 & 2 & 2.8 \\
\hline HRDBLM010 & 2.9 & 2.0 & 2.3 & $2.4 \mathrm{~b}$ & 3.4 & 2 & 2.7 \\
\hline Marpha chaudapat & 2.9 & 3.3 & 2.0 & $2.7 \mathrm{~b}$ & 3.6 & 2 & 2.8 \\
\hline Mean & 2.9 & 3.8 & 1.8 & 3.09 & 3.27 & 2 & 3.13 \\
\hline F-test & $\mathrm{ns}$ & $* *$ & $* *$ & $\mathrm{Ns}$ & $\mathrm{ns}$ & $\mathrm{ns}$ & $\mathrm{ns}$ \\
\hline LSD $(0.05)$ & & 2.022 & 1.075 & 1.84 & & & \\
\hline CV $(\%)$ & 9.5 & 30.2 & 28.44 & 33.6 & 24.97 & 4.6 & 8.4 \\
\hline
\end{tabular}

\section{Leaf size and petiole length}

The averageleaf size; length and width, and weight of harvested leaf was found higher in HRDBLM007which had $85.1 \mathrm{~g}$ and leaf size with $44.9 \mathrm{~cm} \times 29 \mathrm{~cm}$ followed by HRDBLM003 which had $79 \mathrm{~g}$ average leaf weight and leaf size with $48.7 \mathrm{~cm} \times 25.4 \mathrm{~cm}$ (Figure 1-4). Generally harvestingof leaves were done four times in early bolting genotypes and eight to ten times in late bolting genotypes where first harvested leaf and last and near to last harvesting leaves are smaller in size and average leaf weight. The least average leaf weight was recorded in HRDBLM001 $(32.9 \mathrm{~g})$ followed by HRDBLM009 (45.9 g) (Figure 1). Gyawali et al. (2019) has got the highest cumulative leaf weight $47.3 \mathrm{~g}$ in Marpha chaudapat and $36.4 \mathrm{~g}$ in Manakamana in Bhairahawa condition but in this study HRDBLM010 obtained higher cumulative leaf weight. The reason behind this should be due to different climate and geographical condition in mid-hill condition of Khumaltar, Lalitpur. Broad leaf mustard is cool season crop. AS a winter period is longer at khumaltar as compared to Bhairahawa BLM bolts earlier in Bhairahawa as compared to Kathmandu. The longest leaf length $(48.7 \mathrm{~cm})$ was measured in HRDBLM003 followed by HRDBLM007 $(44.9 \mathrm{~cm})$ whereas the shortest leaf length $(31.3 \mathrm{~cm})$ was measured in HRDBLM001 followed by HRDBLM009 $(32.5 \mathrm{~cm})$ respectively (Figure 4). But the widest leaf width $(29 \mathrm{~cm})$ was measured in HRDBLM007 followed by HRDBLM010 $(27.5 \mathrm{~cm})$ whereas the least width $(19.6 \mathrm{~cm})$ was measured in HRDBLM004 
followed by HRDBLM001 $(21.6 \mathrm{~cm}$ ) (Figure 3). As the leaf is thicker in HRDBLM004, leaf weight per unit surface area of the genotype is higher as compared to other genotypes.

Beside this HRDBLM004 does not have petiole without covering leaf blade. Marpha chaudapat has the longest petiole $(2.4 \mathrm{~cm})$ followed by HRDBLM001 $(1.9 \mathrm{CM})$ whereas the least petiole length was measured in HRDBLM010 $(0.93 \mathrm{~cm}$ ) (Figure 2). Shorter petiole length is the desired character for green leafy vegetable; broad leaf mustard cultivar.

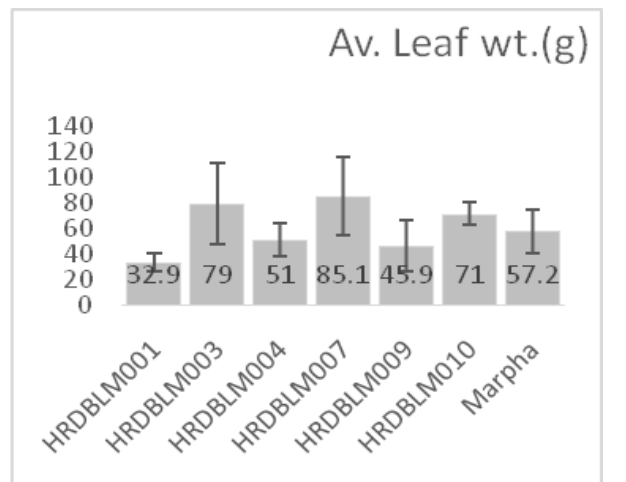

Figure 1. Mean of average leaf weight of BLM

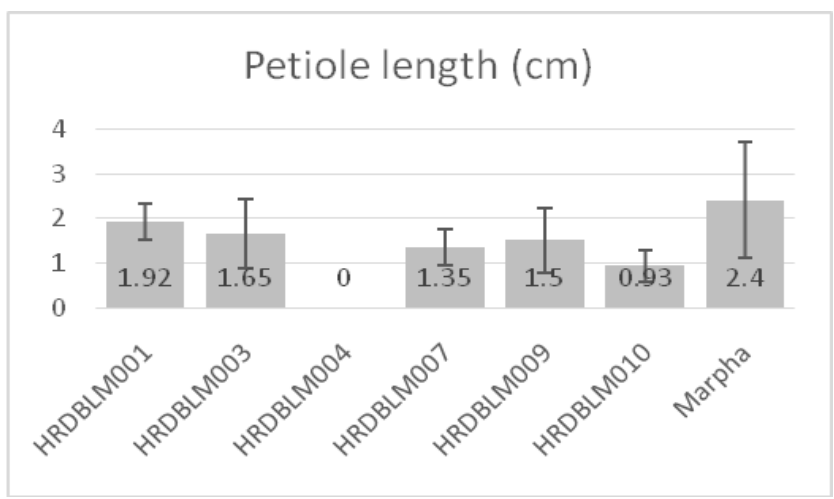

Figure 2. Mean of petiole length of BLM

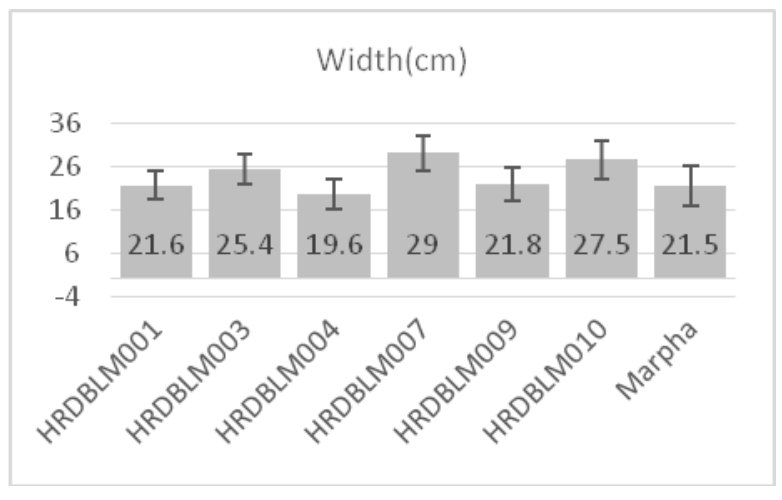

Figure 3. Mean of leaf width of BLM

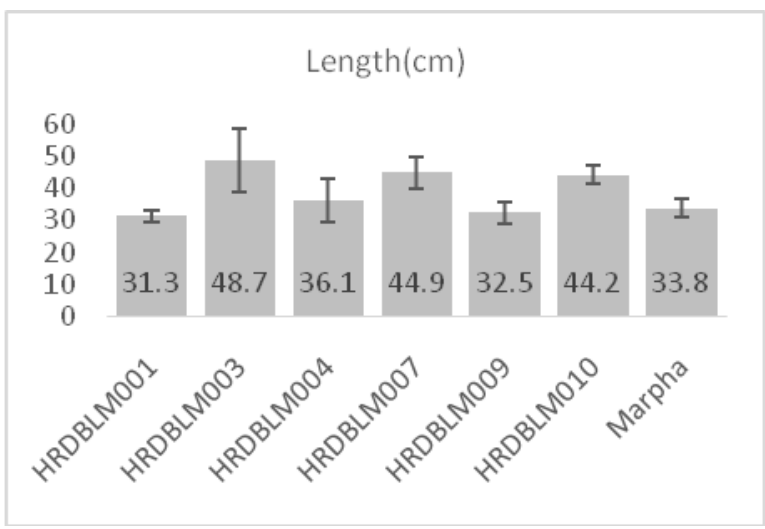

Figure 4. Mean of leaf length of BLM

\section{Leaf yield in number and weight}

Leaf harvest per plant was found highly significant in year 2016 and in 2018 non-significant in year 2017. Combined meannumber of leaf harvest per plant was significantly higher inHRDBLM004 (41.3) followed by HRDBLM010 (25.3) and lowest in Marpha (12.3) followed by HRDBLM009 (17.7) (Table 5). The highest number of leaves harvested per plant in HRDBLM004 was 41 leaves in this study is in line with the result of Pokluda (2007) who had obtained the highest number of leavesi.e. 57 per plant from superior variety "Cai Cai Tai" in Japan. He harvested a greater number of leaves may be due to either grown in green house or variety is suitable and high yielder for that climate. Similarly, mean leaf harvested per plant was also significant effect of the genotypes in 2016 and 2018. In all the years, yield per plant was highest in HRDBLM004 followed by HRDBLM010. Mean leaf yield per plant was obtained significantly highest (848 g) from HRDBLM004 followed by HRDBLM010 (748 g) as compared to check most popular variety Marpha chaudapat (318 g).

\section{Yield ton per hectare}

Average yield (t/ha) obtained from HRDBLM004 (60.10 t/ha) and HRDBLM010 (51.24 t/ha) was significantly higher as compared to check Marpha chaudapat variety (19.43 t/ha). It was significantly higher in the all the tested three years. The combined mean least yield was obtained from HRDBLM001 (19.02 t/ha) followed by Marpha (19.53 t/ha). Combined mean individual leaf weight 
of HRDBLM010 (27.3 g) was significantly higher than HRDBLM004 (14.4 g) but at par to Marpha chaudapat (20 g) (Table 6).

Table 5. Average yield/plant (g) of broad leaf mustard genotypes during 2016, 2017 and 2018, NHRC Khumaltar

\begin{tabular}{lllllllll}
\hline Genotypes & \multicolumn{3}{c}{ Leaf harvested/plant (no.) } & \multicolumn{4}{c}{ Yield/plant (g) } \\
\cline { 2 - 11 } & $\mathbf{2 0 1 6}$ & $\mathbf{2 0 1 7}$ & $\mathbf{2 0 1 8}$ & Average & $\mathbf{2 0 1 6}$ & $\mathbf{2 0 1 7}$ & $\mathbf{2 0 1 8}$ & Average \\
\hline HRDBLM001 & 27 & 22 & 10 & $19.7 \mathrm{~b}$ & 422 & 571 & 247 & $413 \mathrm{c}$ \\
\hline HRDBLM003 & 19 & 19 & - & $19.0 \mathrm{~b}$ & 446 & 337 & - & $391 \mathrm{c}$ \\
\hline HRDBLM004 & 58 & 10 & 56 & $41.3 \mathrm{a}$ & 1013 & 787 & 744 & $848 \mathrm{a}$ \\
\hline HRDBLM007 & 23 & 11 & 32 & $22.0 \mathrm{ab}$ & 694 & 757 & 561 & $671 \mathrm{~b}$ \\
\hline HRDBLM009 & 27 & 17 & 9 & $17.7 \mathrm{~b}$ & 459 & 345 & 186 & $330 \mathrm{c}$ \\
\hline HRDBLM010 & 26 & 20 & 30 & $25.3 \mathrm{ab}$ & 881 & 753 & 609 & $748 \mathrm{ab}$ \\
\hline Marpha chaudapat & 15 & 12 & 10 & $12.3 \mathrm{~b}$ & 472 & 174 & 285 & $318 \mathrm{c}$ \\
\hline Mean & 27.8 & 15.8 & 26.2 & 22.5 & 626.7 & 532 & 438.7 & 530 \\
\hline F-test & $* *$ & $\mathrm{~ns}$ & $* *$ & $*$ & $* *$ & $\mathrm{~ns}$ & $*$ & $* *$ \\
\hline LSD $(0.05)$ & 12.63 & & 11.61 & 20.2 & 260 & & 157 & 168.3 \\
\hline CV $(\%)$ & 23.0 & 62.0 & 26.8 & 50.65 & 23.32 & 61.52 & 20.60 & 17.84 \\
\hline
\end{tabular}

ns: Non-significant, $* *$ Significant at 0.01 probability level and $*$ Significant at 0.05 probability level

Table 6. Average leaf weight $(\mathrm{g})$ and Yield (t/ha) of broad leaf mustard genotypes during 2016,2017 and 2018, NHRC Khumaltar

\begin{tabular}{lllllllll}
\hline Genotypes & \multicolumn{9}{c}{ Av. Leaf wt. (g) } & \multicolumn{4}{c}{ Yield (t/ha) } \\
\cline { 2 - 10 } & $\mathbf{2 0 1 7}$ & $\mathbf{2 0 1 8}$ & $\mathbf{2 0 1 9}$ & Average & $\mathbf{2 0 1 7}$ & $\mathbf{2 0 1 8}$ & $\mathbf{2 0 1 9}$ & Average \\
\hline HRDBLM001 & 15.4 & 22.3 & 24.2 & $20.6 \mathrm{ab}$ & 29.17 & 9.58 & 18.32 & $19.02 \mathrm{~d}$ \\
\hline HRDBLM003 & 23.3 & 19.2 & 13.1 & $18.5 \mathrm{ab}$ & 30.89 & 20.61 & - & $25.75 \mathrm{~d}$ \\
\hline HRDBLM004 & 13.3 & 9.6 & 20.2 & $14.4 \mathrm{~b}$ & 70.02 & 55.14 & 55.14 & $60.10 \mathrm{a}$ \\
\hline HRDBLM007 & 30.1 & 11.3 & 24.9 & $22.1 \mathrm{ab}$ & 48.0 & 35.94 & 40.86 & $41.60 \mathrm{c}$ \\
\hline HRDBLM009 & 16.6 & 17.3 & 20.0 & $18.0 \mathrm{ab}$ & 31.41 & 18.34 & 13.78 & $21.18 \mathrm{~d}$ \\
\hline HRDBLM010 & 33.5 & 19.5 & 28.9 & $27.3 \mathrm{a}$ & 60.25 & 48.30 & 45.16 & $51.24 \mathrm{~b}$ \\
\hline Marpha chaudapat & 31.4 & 12.2 & 16.4 & $20.0 \mathrm{ab}$ & 31.96 & 5.83 & 20.79 & $19.53 \mathrm{~d}$ \\
\hline Mean & 21.21 & 15.9 & 21.10 & 20.13 & 43.10 & 27.67 & 19.86 & 34.06 \\
\hline F-test & $* *$ & $\mathrm{~ns}$ & $*$ & $*$ & $* *$ & $* *$ & $* *$ & $* *$ \\
\hline LSD $(0.05)$ & 8.6 & & 10.49 & 10.89 & 18.25 & 19.62 & 11.09 & 7.22 \\
\hline CV $(\%)$ & 19.71 & 62.04 & 27.93 & 30.40 & 23.79 & 35.07 & 19.86 & 11.92 \\
\hline
\end{tabular}

Leaf characteristics

Leaf blade shape was varied from spathulate (HRDBLM003) to obovate (HRDBLM001, HRDBLM007, HRDBLM009, Marpha). Leaf color is varied from light green (HRDBLM001, HRDBLM009) to dark green with purple vein. Leaf blade blistering is low in HRDBLM004 and high in HRDBLM010 and Marpha chaudapat. Similarly, leaf division margin is varied from entire (HRDBLM004) to serrate (HRDBLM001, HRDBLM010). Leaf blade thickness all most same nature (intermediate) in all the genotypes except HRDBLM004 (thick). Most of the cultivars are soft to medium soft except HRDBLM003 (rough). One of the reasons behind not promoting this HRDBLM003 is its roughness which is not desired. Most of the tested genotypes have very good taste (HRDBLM001, HRDBLM009, HRDBLM010) to excellent taste (Marpha chaudapat) (Table 7).

Table 7. Leaf characteristics of Broad leaf mustard genotypes during 2016, 2017 and 2018, NHRC Khumaltar

\begin{tabular}{lllllllll}
\hline Genotypes & $\begin{array}{l}\text { Leaf blade Leaf } \\
\text { shape }\end{array}$ & color & $\begin{array}{l}\text { Leaf blade } \\
\text { blistering }\end{array}$ & $\begin{array}{l}\text { Leaf } \\
\text { division } \\
\text { margin }\end{array}$ & $\begin{array}{l}\text { Leaf blade } \\
\text { thickness }\end{array}$ & Tenderness & Taste & $\begin{array}{l}\text { Days to } \\
\text { bolting }\end{array}$ \\
\hline HRDBLM001 & obovate & LG & Intermediate & Serrate & intermediate & soft & V.good & late \\
\hline HRDBLM003 & spathulate & Green & Intermediate & Crenate & intermediate & rough & Good & v.early \\
\hline HRDBLM004 & Eleptic & $\begin{array}{l}\text { Dark } \\
\text { Green }\end{array}$ & Low & Entire & thick & soft & good & v.early \\
\hline
\end{tabular}




\begin{tabular}{lllllllll}
\hline Genotypes & $\begin{array}{l}\text { Leaf blade Leaf } \\
\text { shape }\end{array}$ & $\begin{array}{l}\text { Leaf blade } \\
\text { color } \\
\text { blistering }\end{array}$ & $\begin{array}{l}\text { Leaf } \\
\text { division } \\
\text { margin }\end{array}$ & $\begin{array}{l}\text { Leaf blade } \\
\text { thickness }\end{array}$ & Tenderness Taste & $\begin{array}{l}\text { Days to } \\
\text { bolting }\end{array}$ \\
\hline HRDBLM007 & Obovate & DG* $^{*}$ & Intermediate & Crenate & intermediate & Medium soft Good & early \\
\hline HRDBLM009 & Obovate & LG & Intermediate & Crenate & intermediate & soft & V.good & late \\
\hline HRDBLM010 & Oblong & DG $^{*}$ & High & Serrate & intermediate & Medium soft V.good & med \\
\hline $\begin{array}{l}\text { Marpha } \\
\text { chaudapat }\end{array}$ & obovate & Green & High & Crenate & intermediate & soft & Excellent no & no \\
\hline
\end{tabular}

${ }^{\mathrm{x}}$ LG: light green, DG: Dark green, DG* Dark green with purple vein

\section{Responses of consumers and farmers}

Consumers response on size among the genotypes is not significant different however, size of HRDBLM004 wasmore preferred. However, they responded significantly different among the varieties on its leaf shape, color and freshness. Cv. HRDBLM004 and HRDBLM010 were significantly preferred than Marpha chaudapat with respect to leaf shape, color and freshness (Table 8). Similarly, farmers significantly preferred plant appearance of HRDBLM004 (4.0) and HRDBLM010 (4.0) as compared to Marpha chaudapat (3.0) but they preferred HRDBLM004 and HRDBLM010 same as Marpha chaudapat with respect to market preferences. Even though the yield of HRDBLM004 and HRDBLM010 wasnot significantly higher in farmers perspective, but superior than Marpha chaudapat. Among the tested cultivars; farmers expressed that HRDBLM004 and HRDBLM010 were the least damaged by insect pest and HRDBLM010 had least infected with disease and HRDBLM004 was at par with Marpha chaudapat (Table 8). Hence, consumers and farmers had preferred these two cultivars; HRDBLM004 and HRDBLM010 than others.

Table 8. Consumers and farmers acceptance test of the genotypes

\begin{tabular}{|c|c|c|c|c|c|c|c|c|c|}
\hline \multirow[t]{2}{*}{ Genotypes } & \multicolumn{4}{|c|}{ Consumer's response $(1-5) x$} & \multicolumn{3}{|c|}{ Farmer's response $(1-5) x$} & \multirow[b]{2}{*}{ Insect } & \multirow[b]{2}{*}{ Disease } \\
\hline & Size & Shape & Color & Freshness & $\begin{array}{l}\text { Plant } \\
\text { appearance }\end{array}$ & $\begin{array}{l}\text { Market } \\
\text { value }\end{array}$ & Yield & & \\
\hline HRDBLM001 & 3.0 & 2.7 & 2.7 & 2.7 & 3.0 & 2.0 & 2.3 & 1.7 & 2.0 \\
\hline HRDBLM004 & 4.0 & 3.7 & 4.0 & 4.0 & 4.0 & 3.0 & 3.3 & 1.0 & 1.7 \\
\hline HRDBLM007 & 3.7 & 3.3 & 3.3 & 3.0 & 3.3 & 2.3 & 3.0 & 1.7 & 2.0 \\
\hline HRDBLM009 & 3.7 & 3.3 & 3.0 & 2.7 & 3.3 & 2.7 & 3.0 & 2.0 & 2.0 \\
\hline HRDBLM010 & 3.7 & 3.7 & 4.0 & 3.7 & 4.0 & 3.0 & 3.3 & 1.0 & 1.3 \\
\hline $\begin{array}{l}\text { Marpha } \\
\text { chaudapat }\end{array}$ & 3.0 & 2.7 & 2.7 & 2.7 & 3.0 & 3.0 & 2.7 & 1.3 & 1.7 \\
\hline Mean & 3.5 & 3.29 & 3.29 & 3.17 & 3.42 & 2.79 & 3.12 & 1.7 & 1.92 \\
\hline F-test & $\mathrm{ns}$ & $*$ & $*$ & $*$ & $*$ & ns & $*$ & $\mathrm{~ns}$ & ns \\
\hline LSD (0.05) & 1.052 & 1.046 & 1.02 & .810 & .757 & 1.038 & .702 & 1.02 & .843 \\
\hline CV (\%) & 17.22 & 18.16 & 17.7 & 14.62 & 12.57 & 21.23 & 12.83 & 34.95 & 25.14 \\
\hline
\end{tabular}

$\mathrm{x}_{1}$ : unacceptable, 5 : excellent

\section{DISCUSSION}

The homogeneity of growth pattern refers to the plant uniformity. It was recorded by using 1 to 5 rating scale; 1 for very poor, 2 for poor, 3 for fair, 4 for good and 5 for excellent. The combined mean of plant uniformity among the genotypes was not significantly different. The relative degree of foliage mass of a genotype is plant vigor. High plant vigor means high vegetative growth. Vigor was recorded at the time of first harvest using 1 to 5 rating scale; 1 for very poor, 2 for poor, 3 for medium, 4 for vigorous and 5 for very vigorous. The combined mean of plant vigor was found significantly different among the tested genotypes.

Insect and Disease in seven genotypes of broad leaf mustard was scored 1-5 scale 1 for no insect and disease and 5 for higher infestation. The result showed that the variation among the genotypes exists with respect to insect and disease response. It supports the Frankel et al (1995) findings; plant germplasm of a particular crop collected from the local sources provides greater genetic variability and can furnish useful traits to broaden the genetic base of crop species. 
Number of leaves per plant is directly related to the yield. It is assumed that higher the number of leaves, higher will be the yield if other yield parameters such as leaf length and leaf breadth remain same. Pokluda (2007) had mentioned the biggest leaves with the length of $45.9 \mathrm{~cm}$ were formed by cv. Ta TouTsai in his experiment at Japanwas near to this study result that HRDBLM003 and HRDBLM007 had at par with this length.

Leaf yield is the most important parameter of Broad Leaf Mustard. Some earlier report indicated that the yield of BLM varied from 3-21 t/ha in South-East Asia (Asandhi and Sastrosiswojo 1988). The study in Philippines reported that the average yield was $11.6 \mathrm{mt} / \mathrm{ha}$ during 1986 (Valmayor and Tiamzon 1988). This revealed that our available varieties are superior to the South-East Asian varieties of BLM. In Nepal, Khatiwada (2008) reported about 31 t/ha yield in 'Marpha Broad Leaf' variety of BLM planted at $45 \times 30 \mathrm{~cm}$ spacing for summer season crop under periodic harvesting at Dhankuta also supported the present study. In another study, Khatiwada et al (1997) at Pakhribas, Dhankuta, reported that periodic harvesting in BLM could be done up to six months after transplanting. However, in present study, the harvesting of quality leaf was done for two and half months after transplanting. This may be due to difference in climate and planting season of the studied areas. This result is also supported by the Meena et al (2017) that productivity of the mustard is influenced by genotypes.

Late bolting is the preferred trait of the BLM. In Khumaltar condition, Marpha chaudapat has no bolting. So, seed production is not also feasible in Khumaltar (mid-hills) condition. HRDBLM001 and HRDBLM009 were late bolter followed by HRDBLM010. The other three genotypes were early bolter genotypes. Vinu et al. (2013) who had conducted the field evaluation trial during winter 201011 had also shown significant genetic variation supports our result.

\section{CONCLUSION}

On the basis of overall characteristics, among the tested genotypes; HRDBLM010 showed superior performance with good uniformity, vigorous growth, moderately resistant with insect pest and disease (bigger leaf size, least petiole length significantly higher leaf yield in number and wt. (medium late bolting, good taste. The next promising genotype HRDBLM004 had also good uniformity, vigorous, less damage by insect and disease, higher yield in number and weight, and softness. These two cultivars have been recommended for cultivation in Kathmandu valley and other same agro-ecological environment of central mid-hills of Nepal.

\section{ACKNOWLEDGEMENTS}

We would like to acknowledge all the scientists, technical officers, technician and other staffs of National Horticulture Research Center for their support during conducting this experiment and NHRC, NARC for providing budget to conduct study.

\section{REFERENCES}

Asandhi AA and S Sastrosiswojo. 1988. Research on vegetables in Indonesia. In: AVRDC, Vegetable research in South-East Asia. Asian Vegetable Research and Development Center (AVRDC), p. 95-102. Taiwan: Shanhua, Tainan.

Dinssa FF, O Mbwambo, J Macharia, A Aloyce and O Shilla. 2015. Protocols for fruit, leafy and bulb-type vegetable cultivar testing. AVRDC-The World Vegetable Center. Shanhua, Taiwan. Publication Series 15793. p 6.

Dixon CR. 2007. Vegetable brassica and related crucifers. Crop Production Science in Horticulture 14:30-33.

Frankel OH, AHD Brown and JJ Buron. 1995. The Conservation of Plant Biodiversity. Cambridge Univ Press, Cambridge, UK., p.299.

Gomez KA and AA Gomez. 1984. Statistical Procedures for Agricultural Research (2nd ed.). USA: John Wiley and Sons, New York.

Gotame TP, IP Gautam, SL Shrestha and NG Pradhan.2019. A field guide for vegetable germplasm testing, evaluation and variety registration/release. Nepal Agricultural Research Council (NARC), National Agriculture Research Institute (NARI), Horticulture Research Division (HRD), Khumaltar, Lalitpur, NARC Publication Serial No. 00669-683 (2019/20). p.26 
Gyawali S, P Chaudhary, M Chaudhary, S Gurung and R Pathak. 2019. Comparative Evaluation of Broad Leaf Mustard (BLM) under Different Boron Concentrations in Outdoor Barrel Aquaponics at IAAS, Paklihawa Int. J. Appl. Sci. Biotechnol. 7(3): 359-364. DOI: https://10.3126/ijasbt.v7i3.25698

Joshi BK, MR Bhatta, KH Ghimire, M Khanal, SB Gurung, R Dhakal, and BR Sthapit. 2017. Released and Promising Crop Varieties of Mountain Agriculture in Nepal (1959-2016). LI-BIRD, Pokhara; NARC, Kathmandu and Bioversity International, Pokhara, Nepal. https://www.bioversityinternational.org/fileadmin/user_upload/Released_and_promising_crop_varieties.pd $\mathrm{f}$

Khatiwada PP. 2008. Broad Leaf Mustard production during dry season by altering husbandry practices. Nepalese Horticulture 6(1): 47-53.

Kumar V, AK Thakur, ND Barothia and SS Chatterjee. 2011. Therapeutic potentials of Brassica juncea: An overview. Tang International Journal of Genuine Traditional Medicine 1:1-17.

Meena PKP and BL Kumar. 2017. Studies on Response of Mustard Varieties to Different Sowing Dates under Humid Southern Plain Zone of Rajasthan. Int. J. Pure. App. Biosci. 5(3): 385-391-2017.

DOI: http://dx.doi.org/10.18782/2320-7051-4024.

Mohammadi SA and BM Prasanna. 2003. Analysis of genetic diversity in crop plants salient statistical tools and considerations. Review and Interpretation. CropScience, 43, 1235-1248.

MoALD. 2020. Statistical Information on Nepalese Agriculture 2018/19. Ministry of Agriculture and Livestock Development. Statistics and Analysis Section, Singhdurbar, Kathmandu, Nepal.

NHRC. 2019. Annual Report. National Horticulture Research Center, National Agriculture Research Institute, Nepal Agriculture Research Council, Khumaltar, Lalitpur, Nepal.

National Plant Monitoring Scheme, Species identification guide. 2015. https://www.npms.org.uk/sites/default/files/PDF/NPMS\%20ID\%20GUIDE_WEB_0.pdf

Okuno K. 1996. International collaboration for conserving genetic diversity of plant genetic resources. Proceedings of the Tsukuba Asian Seminar on Agricultural Education, (AE'96), University of Tsukuba, lbaraki, Japan, pp. 151-158.

Parajuli A. 2015. Cultivation and Management practices of leafy vegetable in Nepal. .https://parajulianish.wordpress.com/2015/02/13/cultivation-and-management-practices-of-leafyvegetables-in-nepal/

Peter A. 2017. How many servings of vegetables should you eat per day? www.healthline.com/nutrition/servings-of vegetables per day.

Pokluda R.2007. Morphological and nutritional parameters of Chinese mustard (Brassica juncea) in hydroponic culture. Faculty of Horticulture, Mendel University of Agriculture and Forestry Brno, Lednice,Czech Republic. Hort. Sci. (Prague) 34(3): 123-128

Regmi HN, BK Joshi, HB KC, A Subedi, SR Gupta and J Bajracharya. 2005. Locating diversity of broad leaf mustard (Brassica juncea L.) in Nepal. In: On-farm Management of Agricultural Biodiversity in Nepal. Vol I. Assessing the Amount and Distribution of Genetic Diversity On-farm (BR Sthapit, MP Upadyay, SK Shrestha and DI Jarvis, eds). Proc. of the $2^{\text {nd }}$ National Workshop, Nagarkot. IPGRI, Rome; pp.161166. http://books.google.com/books?id=sevX_6fR2xUC\&printsec=frontcover\&source=gbs_navlinks_s

SQCC. 2019. http://www.sqcc.gov.np/images/category/Notified_and_Denotified_Varieties_till_2076_04_07.pdf

Szollosi R. 2011. Indian Mustard (Brassica juncea L.). Seed in health. Department of plant biology, University of Szeged, Hungery. Chapter 78: p.72. In: Nuts and seeds in health and disease prevention. Edited by Victor R. Preedy. Ronald Ross Watson. Vinod B. Patel. British Library cataloguing in Publication data.

Singh SP, RS Katiyar, SK Rai, SM Triphathi and JP Srivastva.2005. Genetic divergence and its implication in breeding of desired plant types in coriander (Coriandrum sativum L.). Genetika 37:155-163.

Valmayor RV and MF Tiamzon. 1988. Vegetable production and research policy in the Philippines. In: AVRDC, 1988a. Vegetable research in South-East Asia. Asian Vegetable Research and Development Center (AVRDC), p.17-30. Taiwan: Shanhua, Tainan

Vinu V, N Singh, S Vasudev, DK Yadava, S Kumar, S Naresh, SR Bhat and KV Prabhu. 2013. Assessment of genetic diversity in Brassica juncea (Brassicaceae)genotypes using phenotypic differences and SSR markers. Rev. Biol. Trop. (Int. J. Trop. Biol. ISSN-0034-7744) 61(4): 1919-1934.

Welsh RJ. 1990. Fundamentals of Plant Genetics and Breeding. John Wiley and Sons, New York.

||------||-------|| 